\title{
The development of communication skills and the teacher's performance in the nursing student's perspective
}

\author{
O desenvolvimento das habilidades comunicativas e a atuação do \\ professor na perspectiva do aluno de enfermagem
}

El desarrollo de las habilidades de comunicación y la actuación del profesor en la perspectiva del alumno de enfermería

Karime Rodrigues Emilio de Oliveira ${ }^{1}$, Eliana Mara Braga²

${ }^{1,2}$ Universidade Estadual Paulista Júlio de Mesquita Filho - Departamento de Enfermagem, FMB, UNESP, Botucatu, São Paulo, Brazil.

\section{ABSTRACT}

Objective: To understand experiences in the development of communication skills and the teacher's role in this teaching-learning process under the perspective of undergraduate nursing students by considering two types of curriculum organization. Method: Descriptive study with a qualitative approach conducted in two public schools located in São Paulo state, Brazil. Data were collected by means of self-completed forms from 81 students in the second and fourth years of the undergraduate program. Results were analyzed in light of Content Analysis. Results: Results showed that the development of such skills is related to: students' individual characteristics, patients' characteristics, those of the health-disease process, the health-care team's profile and the theoretical knowledge acquired on communication in health-care provision and nursing. The teacher's role was perceived as one that supports and encourages interactions with patients and healthcare teams by teaching and providing orientation about interpersonal communication. Conclusion: Students identify and value the importance of their teachers' performance in the development and acquisition of communication skills. Additionally, students who experience active teaching-learning methodologies acknowledge the teacher as essential to provide opportunities for students to express their knowledge and thoughts.

\section{DESCRIPTORS}

Communication; Nursing Education; Aptitude; Faculty, Nursing; Students. 


\section{INTRODUCTION}

Nursing care is expressed through interpersonal relationships and it includes forms of communication. By means of these, nurses welcome the patient, know his/her fears, anxieties, feelings, and health needs. In order to do that, there is a need for nurses to invest in communication skills, decoding the meaning of the messages being sent, and establishing a plan of care that is appropriate to and consistent with the patient's needs ${ }^{(1)}$.

Thus, it is essential that nurses acquire knowledge about the theoretical and methodological framework of human communication, from the beginning of his academic career ${ }^{(2)}$.

A study on the teaching of communication in the nursing curricula shows that both students and faculty members value the communication competencies for sa$\mathrm{fe}$, quality practice. Also, the undergraduate curriculum is critical to the development of this competence, therefore, it is necessary to structure relational components within the undergraduate nursing courses ${ }^{(3)}$.

Therefore, there is a need to build communication skills that lead nursing students to understand the importance of interpersonal relationships and the adequate use of communication in the care context.

Reaffirming the importance of nursing faculty members having communication skills to establish effective teaching-learning relationships ${ }^{(2)}$, the aim of this study was: to understand the experiences in the development of communication skills and the faculty member's role in the teaching-learning process, from the perspective of nursing students, considering two types of curricular organization.

\section{METHOD}

This was a descriptive study, with a qualitative approach used to answer the guiding questions.

A qualitative approach was the best choice to develop this study's theme. It enables the incorporation of the issues of meaning and intentionality as being inherent to actions, relationships and social structures, with the latter considered both in their advent and their transformation as significant human constructions ${ }^{(4)}$.

The study was performed in two public schools in the countryside of the state of São Paulo, Brazil, later identified as Institution 1 and Institution 2.

Institution 1 was selected for the study because it used diverse teaching-learning methodologies in the curricular subjects, i.e., from the traditional to those considered active. Institution 2 was selected because it adopted only active teaching-learning methods institutionally, Problem-Based Learning (PBL) and "Problem-Based Teaching" (PBT), within a curriculum that is integrated and oriented by dialogic competence in nursing education.

With regard to ethical procedures, this study was performed in accordance with Resolution 466/12 of the $\mathrm{Na}-$ tional Health Council (NHC) and the National Research Ethics Commission (NREC) ${ }^{(5)}$, receiving a favorable opinion from the Committee for Ethics in Research (CER) of the involved institutions, under Certificate of Presentation for Ethical Consideration number: 18459013.0.3001.5413.

All nursing students enrolled in the second and fourth years of the educational institutions were invited to participate and instructed about the research objectives, on random days of academic activity.

The individuals who agreed to participate in the study were asked to sign two copies of the Terms of Free and Informed Consent (TFIC), one for the participant and one for the researcher. Freedom of participation was ensured, as well as the participant's right to withdraw permission at any time during the study, without any negative implications or embarrassment.

The choice of the second year students was based on their greater opportunity of having contact with patients and the health care team, thereby enabling them to respond to the format of this study. The fourth year students were selected because they are in the last internship of their major, when there is a greater possibility for them to apply communication skills in practice.

Data collection was performed from August to October of 2014, by means of a two-part, self-administered tool. The first part was related to participant characteristics, with variables such as age, sex, year in major; and, a second part consisted of three guiding questions related to education and the development of communication skills, as follows:

1) What do you find to be the easiest aspects in communicating with patients and the care team in the healthcare environment?

2) What difficulties do you have in communicating with patients and the care team in the healthcare environment?

3) How do you perceive the faculty member's role in the process of building and developing communication skills?

In this study, data were presented and analyzed using content analysis, which is a set of communication analysis techniques that aim to obtain indicators that allow for the inference of knowledge related to the conditions of building/receiving these messages, by means of systematic and objective procedures of description of the content of the message $e^{(6)}$.

In the pre-analysis stage, we completed a complete transcription of the records and a fluctuant reading of the texts, having exhaustive contact with the material ${ }^{(6)}$.

In the analytical description stage, we clipped and selected the reporting units, electing and coding them, given their convergence with the phenomenon. Then we classified the thematic units under a generic title, in a process called semantic categorization ${ }^{(6)}$.

For the treatment of results, we made inferences and interpreted ${ }^{(6)}$ emerging data about the experiences of nursing students when communicating in healthcare environments, and their perceptions about the faculty member's role in developing these skills.

\section{RESULTS}

The study included 81 second and fourth year nursing students from two public schools: 24 second year students and 21 fourth year students from Institution 1, and 28 
second year students and eight fourth year students from Institution 2.

The prevalent age groups in the second year students of Institutions 1 and 2 were 20 and 19 years, respectively. Regarding the fourth year students, the prevalent age groups were 22 and 21 years in Institutions 1 and 2, respectively.

Regarding gender, there was a prevalence of women, with the overall participation of 75 students.

From the perspective of second and fourth year nursing students, the easy and difficult aspects of communicating with patients and the care team in health environments were related to the following factors:

- Students' personal characteristics;

- Individual characteristics of patients and the health-disease process;

- $\quad$ Profile of the health teams;

- Theoretical knowledge about communication in health and nursing.

\section{STUDENTS' PERSONAL CHARACTERISTICS}

From the data analysis, it was noted that the experience of difficult and easy aspects of communication is primarily associated with the individuality of the student, i.e., his/her personality.

This analysis is also corroborated by the fact that communication skills exist both in those students who are just beginning the major, and communication weaknesses exist in those who are nearing the end of the major: those with more theoretical background on the concepts of health, communication references, and greater opportunities to experience relationships in healthcare environments.

"I find it quite easy to communicate. I explain as much as possible with appropriate language. I repeat whenever necessary ... "(Student 78, year 2, Institution 1)

"My difficulty is the fact that I'm shy, soft-spoken, which inadvertently makes patients insecure." (Student 24, year 2, Institution 2)

"I've always had communication difficulties and shyness has always been a problem for me. That is a major barrier for communication with the team and patients. "(Student 42, year 4, Institution 1)

"I'm a communicative person, I don't have trouble communicating. I find it easy to approach patients about various subjects ... "(Student 8, year 4, Institution 2)

\section{INDIVIDUAL CHARACTERISTICS OF PATIENTS AND THE HEALTH=DISEASE PROCESS}

The study's participants believe that characteristics related to the individuality of patients and the health-disease process interfere with and make communication complicated, such as: the impossibility of verbal and nonverbal expression in critically ill patients, pain, verbosity, shy patients, those resistant to treatments, procedures, and opinions.
The initial moment, i.e., the establishment of the first contact with patients, is considered to be the most difficult moment of interaction by the students, because they do not as yet have a connection with the patients.

The students participating in the study also reported that the most difficult issues to approach are death, sexuality, and religion.

"It's difficult when the patient is quieter and you talk
to him, and his speech is very brief, he does not give
you opportunities to delve further." (Student 67, year
2, Institution 1)

"My communication becomes easier because the patients show interest in their health status and want to resolve many concerns." (Student 32, year 2, Institution 2)

"The lack of receptivity, the hostile way the patient behaves, the pain barrier, all of that will often cause difficulty with relating to the patient." (Student 54, year 4, Institution 1)

"Shy and introverted patients make contact difficult." (Student 5, year 4, Institution 2)

\section{Profile of health teams}

For nursing students, the profile of health team, i.e., the way they are welcomed, receptivity, attention and resistance to students' opinions, can facilitate or develop barriers to the relationship that they establish with this group of professionals.

From the data analysis, it was noted that there were differences in the relationship that the second year students in Institution 1 and Institution 2 established with their respective teams. Second year students in Institution $1 \mathrm{sta}-$ ted that they had little contact with these groups, which was often linked to the information recorded in the medical charts by these professionals, which they found to be incomplete and lacking in clarity. This contrasts with the second year students of Institution 2; they expressed having regular contact with the teams of the Family Health Units (FHU) and noted that they usually contributed to their learning.

\footnotetext{
"I haven't had much contact with the team in the healthcare environment ..." (Student 69, year 2, Institution 1)

"... the team where I am is very open to communication and always available to work on my learning." (Student 34, year 2, Institution 2)

"... the difficulty communicating with professionals is due to lack of "openness" of the professional to relate to the students." (Student 39, year 4, Institution 1)

"It's difficult when we can't find professionals willing to collaborate, some have their opinions formed, and do not accept others who are different." (Student 3, year 4, Institution 2).
} 


\section{THEORETICAL KNOWLEDGE ABOUT COMMUNICATION IN HEALTH AND NURSING}

The students expressed in their records how important it was to know the theoretical framework of interpersonal communication and have previous nursing knowledge in order to relate to patients.

Students stated that, when there was no previous theoretical knowledge, they felt insecure interacting with patients. However, when they are cognitively strengthened, they felt more confident and prepared to initiate interactions with patients and build an effective connection.

It is important to highlight the recognition and value attributed to the specific disciplines that approach the nurse-patient relationship, by fourth year students of Institution 1 . They expressed that the lessons learned favored experiences in healthcare environments.

"The greatest difficulty is talking to the patient about his required treatment and care." (Student 73 , year 2, Institution 1)

"My greatest difficulty is making sure of a possible diagnosis I make in my mind, and subsequently the plan of care I'll perform ... doing it all with clarity and absolute certainty is a bit difficult." (Student 24, year 2, Institution 2)

"The easy aspects for me were acquired within the nurse-patient relationship courses. I've learned to be more careful in interpersonal and group approaches, as well as paying more attention to non-verbal expressions of people ..." (Student 49, year 4, Institution 1)

"Previous knowledge makes communication easy and effective, as well as the knowledge domain. They make me feel safe, facilitating the conversation." (Student 8 , year 4, Institution 2)

Regarding the nursing faculty member's role in developing these skills, students pointed that faculty members act by:

- Supporting and encouraging interaction with patients and health teams;

- Teaching and advising on interpersonal communication;

- Encouraging the participation and expression of thoughts and knowledge in small groups.

\section{SUPPORTING AND ENCOURAGING INTERACTION WITH PATIENTS AND HEALTH TEAMS}

The students emphasized that faculty members provide support, clarify concerns, and help them interact with patients and health teams, being present in moments of interaction and encouraging them to practice communication.

"The faculty member often acts as a mediator, helping build effective communication." (Student 71, year 2, Institution 1)
"The faculty member seeks to encourage the student to have adequate language with patients and develop empathy..." (Student 32, year 2, Institution 2)

"The faculty member has a greater ability to intervene in communication when we, students, "stall"..." (Student 48, year 4, Institution 1)

"They've always helped a lot, both in approach, and in dealing with situations." (Student 2, year 4, Institution 2)

\section{TEACHING AND ADVISING ABOUT INTERPERSONAL COMMUNICATION}

The students participating in the study recognized and valued the faculty members' teaching and instruction on the acquisition of communication skills.

They highlight that educators acted by teaching techniques of how to approach patients and teams, avoiding communication barriers, appropriate behavior in healthcare environments, and the importance of clear and correct charting.
"She teaches about communication and the importance of correct charting." (Student 61, year 2, Institution 1)
"The faculty member seeks to encourage students to have adequate language with patients, and stimula- tes us to develop empathy." (Student 32, year 2, Ins- titution 2)
"The faculty member had a fundamental importance because he taught about the types of communication, how to avoid communication barriers, and how to get around them." (Student 50, year 4, Institution 1)
"... mentions what is and what is not adequate to say to patients and the team." (Student 6, year 4, Insti- tution 2).

\section{ENCOURAGING PARTICIPATION AND EXPRESSION OF THOUGHTS AND KNOWLEDGE IN SMALL GROUPS}

The nursing students of Institution 2 expressed that one of the ways that faculty members act to build communication skills is by encouraging students' verbal expression in discussions related to learning in small groups, urging them to expose their knowledge and questions, encouraging and promoting self-reflection.

"The faculty member encourages the student to talk about the discussed topics, the group dynamics and personal growth. He encourages us to look at ourselves and have a perception of things; has us make sure we can express ourselves because we're in a safe place to do so." (Student 29, year 2, Institution 2)

I think the faculty members here are very helpful in developing communication, encouraging student participation in discussions. In this method, we have to talk all the time and are evaluated for this. I think the focus is the students and their participation, so we need to talk. They act by stimulating student participation." (Student 3, year 4, Institution 2). 


\section{DISCUSSION}

In our study, emerging results indicate that the personal characteristics of students significantly influence the development of communication skills, emphasizing the importance of considering the individuality of the subjects when studying relational processes.

The importance of the nurse's self-knowledge is highlighted by authors ${ }^{(1,2)}$ that state the need for nurses to invest in understanding their actions, and reactions of individuals with whom they interact, in order to establish effective communication.

Self-knowledge is essential to care, because the more nurses know, the more they will be able to minimize or avoid influences of their beliefs and values when interacting with the patient ${ }^{(1,7)}$.

This study showed that students perceive themselves, because they could report easy and difficult aspects in the development of communication skills, therefore they are developing self-knowledge, which, from the perspective of theoretical communication, is essential for care. In addition, they considered that the characteristics related to patients and the health-disease process interfere with interpersonal relationships.

A study approaching the teaching-service integration in professional training demonstrated the difficulty with health team professionals participating in academic activities, considering it a constant challenge to integrate the students' practices into the daily health service routine, due to the increasing routines of the units and users' demands ${ }^{(7)}$.

When we interact with someone, we must consider that the environment influences the quality of communication and results, because the temperature, noise in care settings, and the presence of strangers, can be some of the challenges faced by nurses when trying to stimulate communicative expression of patients ${ }^{(1)}$.

Therefore, the need for students to learn how to recognize communication barriers and to know how to perform in different situations is emphasized.

Another study aiming to know the implications of the teaching-service integration for training in nursing from the perspective of faculty members, students and professionals of health services, points to evidence of weaknesses in the context of interpersonal relationships, resistance and indifference of professionals towards nursing students, because they think that supporting them in learning is an overload given their work demands ${ }^{(8)}$.

In our study, the difference between educational institutions and students' interaction with the health teams were noted. Students of Institution 1 demonstrated a fragile and distant relationship with the teams. In contrast, students of Institution 2, integrated into active methods of teaching and learning, felt they were a part of the team.

Another study performed in undergraduate courses using active learning methodologies affirmed that this allows for frequent contact of students with health professionals, valuing the space of articulation among education, service and community, and aim to integrate training with the world of work ${ }^{(9)}$.
It is also important to point out that the students in our study highlighted the importance of theoretical knowledge in interpersonal communication and nursing for establishing effective emotional connections in health environments, emphasizing that a deficit of theoretical frameworks can undermine interactions.

The current challenge in the nursing education process is highlighted in a study that showed that many nursing students were unprepared for higher education, due to a lack of prior knowledge related to primary and secondary school content ${ }^{(10)}$, corroborated with our research when second year students of Institution 2 reported insecurity in relating the theoretical knowledge with practice, whereas the fourth year students reported security in personal relationships, when grounded in theoretical knowledge.

Another study on the strengths and weaknesses of active learning methodologies highlighted that students felt lost in their search for knowledge, especially in basic subjects, due to the abrupt change from the traditional method of teaching to the active method. This change, from the students' perspective, led to insecurity, required a great effort of the actors involved in the process, and required behavioral change, as well as maturity and organization ${ }^{(11)}$.

Regarding the faculty member's role, the results emerging from our research pointed to the faculty as an essential element in the development of communication skills, because he acted as a mediator, encouraged communicative approaches, taught, and provided guidance on interpersonal communication.

The proximity of the faculty-student relationship was highlighted in practical activities as favoring the relationship, considering that nursing faculty members felt responsible for creating an environment conducive to learning, both in relationships they established with the students and with health professionals ${ }^{(12)}$.

Therefore, practice is essential in the development of communication skills, allowing for greater proximity between faculty-student, and it provides opportunities for faculty members to support and encourage the students' interaction with patients and the health team.

The participants of our study also stated that they perceived faculty members were working to develop these skills, teaching, and guidance on interpersonal communication. Related to this issue, there is a study suggesting that faculty members include practical applications, putting students in difficult situations, which require empathic communication skills with patients, and recommend practical simulation exercises to promote the development of relational skills on students ${ }^{(13)}$.

Nurse faculty members, participants in another study, stated that their skills go beyond the transmission of knowledge. According to them, the educator should be considered a mediator in the process of knowledge construction, with the subject being able to deconstruct and construct knowledge ${ }^{(14)}$.

In addition, it is necessary that faculty members are aware of communication skills they expect from students at each stage of learning, and that it is consistent with the 
expectations of the students, in order not to generate inconsistencies ${ }^{(15)}$.

In active methodologies, the faculty member must assume the role of guiding the teaching-learning process, not just as a spectator, but as one who performs reciprocal exchanges, favors the autonomy of students, and encourages critical and reflective thinking ${ }^{(16)}$.

In active learning methods, faculty members are responsible for guiding students in the phases of PBL and PBT, in monitoring group work and encouraging students to express their thoughts, ideas, and knowledge. In addition, it is also the role of faculty members to work with the dynamics of interpersonal relationships and conflicts, as well as being sensitive in the process of group development $^{(17)}$. These data are consistent with the results of our study, pointing to the role of nursing faculty members as being instrumental in developing communication skills, especially in creating opportunities for expression of thoughts, knowledge and participation of students in small group discussions.

\section{CONCLUSION}

In conclusion, the development of communication skills in nursing students happens under the influence of factors such as personal characteristics, the profile of health teams, knowledge about communication in health and nursing, as well as individual patient characteristics and health-disease process.

Regarding the faculty member's role in the development of communication skills, the students expressed that they supported and encouraged interaction with patients and health teams and taught and provided guidance on interpersonal communication. In addition, students who experienced active methods of teaching and learning recognized the essential role of nursing faculty in the development of communication skills, to create opportunities for expression of students' thoughts in small group discussions. For these students, this teaching practicwwe, characteristic of active teaching-learning methods, significantly contributes to the acquisition of communication skills.

\section{RESUMO}

Objetivo: compreender, sob a ótica de graduandos de enfermagem, as experiências no desenvolvimento de habilidades comunicativas e a atuação do professor neste processo de ensino-aprendizagem, considerando dois tipos de organização curricular. Método: pesquisa descritiva com abordagem qualitativa, realizada em duas instituições de ensino públicas, situadas no interior do estado de São Paulo, Brasil. A coleta dos dados foi realizada pelo autopreenchimento de formulário por 81 alunos de segundo e quartos anos da graduação. Os resultados foram analisados à luz da Análise de Conteúdo. Resultados: revelaram que o desenvolvimento desta habilidade está relacionado à: características individuais dos alunos, dos pacientes, do processo saúde-doença, perfil da equipe e dos conhecimentos teóricos sobre comunicação em saúde e em enfermagem. O papel do professor foi percebido apoiando e incentivando as interações com pacientes e equipes de saúde e ensinando e orientando sobre comunicação interpessoal. Conclusão: Os alunos identificam e valorizam a importância da atuação de seus professores no desenvolvimento e aquisição de habilidades comunicativas. Além disso, os estudantes que vivenciaram as metodologias ativas de ensino-aprendizagem reconhecem o docente essencial para oportunizar a expressão de conhecimentos e pensamentos dos alunos.

\section{DESCRITORES}

Comunicação; Educação em Enfermagem; Habilidade; Docentes de Enfermagem; Estudantes de Enfermagem.

\section{RESUMEN}

Objetivo: Comprender bajo la óptica de los estudiantes de enfermería de pregrado las experiencias en el desarrollo de habilidades de comunicación y la actuación del profesor en este proceso de enseñanza y aprendizaje, considerando dos tipos de organización curricular. Método: Investigación descriptiva con enfoque cualitativo, realizada en dos instituciones de educación públicas, ubicadas en el interior de San Pablo, Brasil. La recolección de los datos fue hecha con el auto llenado de un formulario por 81 alumnos del segundo y cuarto año de pregrado. Los resultados se examinaron con base en el Análisis de Contenido. Resultados: Revelaron que el desarrollo de esta habilidad está relacionado a: las características individuales de los alumnos, de los pacientes, del proceso de salud y enfermedad, al perfil del equipo y de los conocimientos teóricos adquiridos sobre comunicación en salud y en enfermería. El papel del profesor fue percibido apoyando e incentivando las interacciones con pacientes y equipos de salud, enseñando y orientando sobre la comunicación interpersonal. Conclusión: Los alumnos identifican y valorizan que tan importante es la actuación de sus profesores en el desarrollo y adquisición de habilidades en la comunicación. Por otra parte, los estudiantes que experimentaron las metodologías activas de enseñanza y aprendizaje reconocen al docente parte esencial para crear oportunidades en la expresión de conocimientos y pensamientos de los estudiantes.

\section{DESCRIPTORES}

Comunicación; Educación en Enfermería; Aptitud; Docentes de Enfermería; Estudiantes de Enfermería.

\section{REFERENCES}

1. Stefanelli MC, Carvalho EC, organizadores. A comunicação nos diferentes contextos da enfermagem. 2a ed. Barueri: Manole; 2012.

2. Braga EM, Silva MJP. How communication experts Express comunicative competence. Interface (Botucatu). 2010; 14 (34): 529-38.

3. Boschma G, Einboden R, Groening M, Jackson C, MacPhee M, Marshall H, et al. Strengthening communication education in an undergraduate nursing curriculum. Int J Nurs Educ Scholarsh. 2010; 7(1): 1-14. doi:10.2202/1548-923X.2043 
4. Minayo MCS, Deslandes SF, organizador. Pesquisa social: teoria, método e criatividade. 33a ed. Petrópolis: Vozes; 2013.

5. Ministério da Saúde [Internet]. Conselho Nacional de Saúde. Resolução n. 466/2012, de 12 de dezembro de 2012 . Diretrizes e normas regulamentadoras sobre pesquisas envolvendo seres humanos. 2012 [acesso 2014 Set 29]. Disponível em: http://conselho.saude.gov.br/resolucoes/2012/ Reso466.pdf

6. Bardin L. Análise de conteúdo. 5a ed. São Paulo: Edições 70; 2011.

7. Pizzinato A, Gustavo AS, Santos BRL, Ojeda BS, Ferreira E, Thiesen FV, et al. A integração ensino-serviço como estratégia na formação profissional para o SUS. Rev Bras Educ Med. 2012; 36 (1 Supl 2):170-7.

8. Brehmer LCF, Ramos FRS. Teaching-service integration: implications and roles in experiences of undergraduate courses in nursing. Rev Esc Enferm USP. 2014; 48 (1): 119-26.

9. Costa MCG, Francisco AM, Hamamoto CG. O envolvimento de diferentes parcerias na formação do profissional em saúde. In: Moraes MAA, Tonhom SFR, Hafner MLMB, Gomes R, organizadores. Avaliação nos cursos de medicina e enfermagem perspectivas e desafios. Curitiba: CRV; 2012.p. 187

10. Silva KL, Sena RR, Silveira MR, Tavares TS, Silva PM. Desafios da formação do enfermeiro no contexto da expansão do ensino superior. Esc Anna Nery. 2012; 16(2): 380-7.

11. Marin MJS, Lima EFG, Pavioti ABM, Matsuyama DT, Silva LKD, Gonzalez C, et al. Aspectos das fortalezas e fragilidades no uso das metodologias ativas de aprendizagem. Rev Bras Educ Méd. 2010; 34 (1):13-20.

12. Guedes GF, Ohara CVS, Silva GTR. Intensive care unit: a significant space for the professor-student relationship. Acta Paul Enferm. 2012; 25(2):146-50.

13. McMillan LR, Shannon D. Program evaluation of nursing school instruction in measuring students' perceived competence to empathetically communicate with patients. Nurs Educ Perspect. 2011.32(3):150-4.

14. Sebold LF, Carraro TE. Ways of being nurse-teacher-teaching-nursing-care: a heideggerian look. Rev Bras Enferm. 2013 ; 66 (4):550-6.

15. Werinch M, Jackson MB, Scherpbier AJ, Wolfhagen IH, Ramsey PG, Goldstein EA. Ready or not? Expectations of faculty and medical students for clinical skills preparation for clerkships. Med Educ Online. 2010; 15:5295.

16. Paranhos VD, Mendes MMR. Competency-based curriculum and active methodology: perceptions of nursing students. Rev Latino-Am Enferm. 2010; 18(1): [07 telas].

17. Almeida EG, Batista NA. Desempenho docente no contexto PBL: essência para aprendizagem e formação médica. Rev Bras Educ Med. 2013 ; 37 (2):192-201. 